\title{
Trophic linkage among heterotrophic nanoflagellates, ciliates and metazoan zooplankton in a hypereutrophic pond
}

\author{
Shin-ichi Nakano ${ }^{1, *}$, Pathmalal M. Manage ${ }^{1}$, Yuichiro Nishibe ${ }^{1}$, \\ Zen'ichiro Kawabata ${ }^{2}$
}

\begin{abstract}
${ }^{1}$ Center for Marine Environmental Studies, Ehime University, Bunkyo-cho 3, Matsuyama 790-8577, Ehime, Japan
${ }^{2}$ Center for Ecological Research, Kyoto University, Otsuka 509-3, Kamitanakami Hirano-cho Aza, Otsu 520-2113,
\end{abstract} Shiga, Japan

\begin{abstract}
We examined seasonal abundance, production and loss to predation of heterotrophic nanoflagellates (HNF) and ciliates in order to clarify food linkages among HNF, ciliates and metazoan zooplankton in a hypereutrophic pond. Production and loss rates of the protists were estimated using size fractionation $(<5 \mu \mathrm{m},<30 \mu \mathrm{m}$ and total) experiments. There were coupled oscillations in seasonal abundance between HNF and ciliates, whereas we found none between the protists and metazoan zooplankton. Seasonal trends in production of HNF (-12.4 to $86.4 \mathrm{ng} \mathrm{C} \mathrm{ml}^{-1} \mathrm{~d}^{-1}$ ) and predation rates on them by ciliates $\left(-25.6\right.$ to $\left.52.2 \mathrm{ng} \mathrm{C} \mathrm{ml}^{-1} \mathrm{~d}^{-1}\right)$ were similar. There were significant correlations $(\mathrm{p}<$ 0.05 ) between HNF production and predation on HNF by ciliates. These results indicate that ciliates are major consumers of HNF, but we have insufficient evidence of predation on HNF by metazoan predators to do more than suggest that food linkage between HNF and metazoan predators is not substantial. The dominant ciliate species were Cinetochilum margaritaceum, Urotricha spp., Halteria grandinella and Cyclidium glaucoma. Growth rates of Urotricha and Cyclidium populations were enhanced by removal of metazoan predators when the ciliates were dominant. We detected substantial predation pressure on Urotricha spp. during its period of dominance and found a significant correlation $(\mathrm{p}<0.02)$ between production and predation of C. glaucoma. Thus, we suggest that there are active food linkages between these 2 ciliates and metazoan predators. For $C$. margaritaceum and $H$. grandinella, we did not have enough evidence to suggest predation by metazoan predators. Thus, we showed over a $1 \mathrm{yr}$ period that HNF production was almost balanced by loss to predation by ciliates, and that loss processes other than predation might be important for some ciliate taxa.
\end{abstract}

KEY WORDS: Microbial food web · Heterotrophic nanoflagellates $\cdot$ Ciliates $\cdot$ Metazoan zooplankton · Food linkage $\cdot$ Hypereutrophic lake

Resale or republication not permitted without written consent of the publisher

\section{INTRODUCTION}

It has been suggested that microbial food webs may be important supply routes of organic matter to metazoan zooplankton in freshwater environments. The roles of planktonic protists, such as heterotrophic nanoflagellates (HNF) and ciliates, in microbial food

*E-mail: shin@agr.ehime-u.ac.jp webs are to consume bacteria that are too small to serve directly as major prey items for most zooplankters and to be themselves consumed by the zooplankton. There is a consensus that food linkages between bacteria and protists are substantial in many lakes (Nagata 1988, Bloem \& Bar-Gilissen 1989, Sanders et al. 1989, Šimek et al. 1990, 1995, Šimek \& Straskrabova 1992, Nakano et al. 1998a,b) but information is still limited about food linkages between protists and metazoan zooplankton. 
It is now well documented that HNF are heavily predated by the cladoceran Daphnia (Pace et al. 1990, Carrick et al. 1991, Weisse 1991, Pace \& Vaque 1994, Jürgens 1994, Nakano et al. 1998b) and that calanoid copepods (Carrick et al. 1991), rotifers (Dolan \& Gallegos 1991, Weisse 1991) and ciliates (Weisse et al. 1990, Weisse 1991) are also important predators of HNF. However, predation on HNF has not yet been fully examined compared with that on ciliates and more information is needed about which heterotrophs are responsible for controlling the abundance of HNF in lakes.

For ciliates, there has been some examination of predation by planktonic crustaceans in field experiments and the cladoceran Daphnia (Carrick et al. 1991, Pace \& Funke 1991, Brett et al. 1994, Marchessault \& Mazumder 1997, Jürgens et al. 1999), and calanoid (Carrick et al. 1991, Burns \& Schallenberg 1996) and cyclopoid copepods (Weisse et al. 1990, Brett et al. 1994, Wiackowski et al. 1994, Dobberfuhl et al. 1997, Hansen 2000) are all reported to prey on ciliates in lakes. Rotifers are also important predators of ciliates but their impact may be modest relative to that of crustaceans (Jürgens et al. 1999). In contrast, Havens \& Beaver (1997) have reported that densities of dominant ciliate taxa were not affected by removal of zooplankton $>114 \mu \mathrm{m}$ in most of their experiments. Thus, further studies are still needed to collect information about food linkages between ciliates and metazoan zooplankton, although the interactions between them may be taxon specific for both the predators and the prey (Wiackowski et al. 1994, Havens \& Beaver 1997).

In our earlier work (Nakano et al. 1998a), we showed an abundance of both HNF and ciliates in Furuike Pond, suggesting active feeding links between these groups of protists. Small ciliates were dominant: Cinetochilum margaritaceum, Cyclidium glaucoma, Urotricha spp. and Halteria grandinella. The dominant crustaceans were cyclopoid copepods, but their abundance was low (mean 31 ind. $\mathrm{l}^{-1}$ ). At that time the abundance of rotifers had not yet been clarified and this is examined in the present study. We therefore studied the seasonal abundance, production and loss to predation of HNF and ciliates in this hypereutrophic pond in order to examine the hypothesis that production of HNF and ciliates would be balanced by predation.

\section{MATERIALS AND METHODS}

Furuike Pond (Sancho, Matsuyama City, Ehime, Japan) has a surface area of ca $7400 \mathrm{~m}^{2}$ and maximum depth of $1.5 \mathrm{~m}$ and receives anthropogenic loading, primarily from domestic waste water. The concentration of total phosphorus ranged between 100 and
$800 \mu \mathrm{g} \mathrm{l}^{-1}$ (M. Miyagaki \& S. Nakano unpubl. data), indicating that the pond is hypereutrophic (Lampert \& Sommer 1997). Water samples were collected monthly from the surface with an 81 bucket at a near-shore station (Nakano et al. 1998a) from September 1998 to August 1999. There is a horizontal, clockwise eddy in the pond that mixes pelagic and near-shore waters (Nakano et al. 1998a). The eddy is caused by a sea breeze even when the wind is weak, and thus its presence was probably continuous during the study period. We therefore regarded the biological processes in the water samples collected as planktonic and typical of those throughout the pond. All samples were taken at around the same time of day $(09: 30$ to $10: 30 \mathrm{~h})$. The water temperature was measured with a thermistor (TOA Electronics Co. Ltd, Tokyo, Japan).

To determine chlorophyll a concentration, a measured portion of each water sample was filtered through a $0.2 \mu \mathrm{m}$ Nuclepore filter to retain seston. The filter was placed in a glass test tube and $6 \mathrm{ml}$ of $\mathrm{N}, \mathrm{N}$ dimethylformamide was added to extract the chlorophyll $a$, whose quantity was then determined by the fluorometric method (Moran \& Porath 1980).

Immediately after collection, two $100 \mathrm{ml}$ portions of the water sample were fixed, one with glutaraldehyde to a final concentration of $1 \%$ for enumeration of bacteria and HNF and the other with acidified Lugol's solution to a final concentration of $1 \%$ for enumeration of ciliates. Bacteria and HNF were counted using an epifluorescence microscope with ultraviolet excitation (excitation wave length 330 to $385 \mathrm{~nm}$ ) using the DAPI (Porter \& Feig 1980) and primulin (Caron 1983) staining methods, respectively. Two to $5 \mathrm{ml}$ of fixed water sample was filtered through a black-stained Nuclepore filter (pore size $0.8 \mu \mathrm{m}$ ), and seston retained on the filter was stained with primulin. We counted nanoflagellates as HNF if they showed no obvious red chlorophyll fluorescence under the green excitation. Since the cell shapes of some ciliate species may change due to fixation, an unfixed portion of the water sample was brought to our laboratory and the dominant ciliate species were identified under a microscope within $1 \mathrm{~h}$ of collection using the classification guides of Taylor \& Sanders (1991), Patterson \& Hedley (1992) and Foissner \& Berger (1996). We used 10\% methylcellulose solution to slow down swimming ciliates. The ciliate sample fixed with acid Lugol's solution was concentrated by natural sedimentation in a glass cylinder. The sample thus concentrated was poured into a tapered glass tube whose volume was already measured and concentrated again by natural sedimentation. Each species of ciliate was counted in a Burker-Turk type hematocytometer under a microscope.

For counting metazoan zooplankton, measured volumes of between 5 and 201 of water were filtered 
through plankton nets to concentrate the zooplankton, which were then fixed with acid Lugol's solution at a final concentration of $1 \%$. We used a $20 \mu \mathrm{m}$ mesh plankton net for rotifers and a $71 \mu \mathrm{m}$ net for crustaceans. The fixed sample was concentrated by natural sedimentation in a glass cylinder. A 0.2 to $1 \mathrm{ml}$ aliquot of the concentrated sample was taken using a pipette and all the zooplankters were counted, in at least 3 aliquots, on a scaled glass slide.

Since the concentrations of seston in Furuike Pond were quite high, we used plankton nets with mesh sizes of 5 and $30 \mu \mathrm{m}$ for size fractionation. A $5 \mu \mathrm{m}$ mesh plankton net retained ciliates, rotifers and crustaceans, and a $30 \mu \mathrm{m}$ net retained rotifers and crustaceans. Thus, both of the filtrates were assumed to contain bacteria plus $\mathrm{HNF}_{\text {, }}$ and the filtrate of the $30 \mu \mathrm{m}$ net also contained ciliates. We calculated percentages of HNF and ciliates found in the $<5 \mu \mathrm{m}$ or $<30 \mu \mathrm{m}$ fractions $(F)$ as follows:

$$
F=N_{\text {fil }} \times 100 / N_{\text {tot }}
$$

where $N_{\text {fil }}$ is cell density of HNF or ciliates in the $<5 \mu \mathrm{m}$ or $<30 \mu \mathrm{m}$ fraction and $N_{\text {tot }}$ is cell density of HNF or ciliates in non-treated water sample (total fraction).

Two hundred milliliter aliquots of the water samples that had been screened through each plankton net and untreated water samples were poured into polycarbonate bottles. We prepared triplicate bottles of each fraction and of the untreated water. They were incubated in the dark at the sampling station for $24 \mathrm{~h}$. After this in situ incubation, a $100 \mathrm{ml}$ portion of each sample was fixed with glutaraldehyde at a final concentration of $1 \%$ for enumeration of HNF and another $100 \mathrm{ml}$ portion was fixed with acid Lugol's solution for enumeration of ciliates. We also prepared parallel samples with these fixatives for each size-fraction at the start of the incubation period. We thus determined cell densities of HNF and ciliates at the beginning and end of incubation, and population growth rates of the HNF or ciliates were calculated as follows: $\mu=\left(\ln N_{t}-\ln N_{0}\right) / t$, where $\mu$ is growth rate $\left(\mathrm{d}^{-1}\right), N_{0}$ and $N_{t}$ are cell densities of HNF or ciliates at the beginning and end, respectively, of incubation and $t$ is incubation time (d). We assumed that HNF growth in the $<5 \mu \mathrm{m}$ fraction and ciliate growth in the $<30 \mu \mathrm{m}$ fraction were exponential, and that predation rates on HNF by predators in the total fraction were constant. Means and SD of the growth rates of the HNF and of each ciliate taxon in each size fraction were calculated. We determined rates of production $\left(P\right.$, cells $\left.\mathrm{ml}^{-1} \mathrm{~d}^{-1}\right)$ and loss to predation $(L$, cells $\mathrm{ml}^{-1} \mathrm{~d}^{-1}$ ) as follows:

$$
\begin{gathered}
P=\left(\mu_{\text {small }} / \mu_{\text {large }}\right) \times N_{0} \times\left(\mathrm{e}^{\mu_{\text {large }}}-1\right) \\
L=\left[\left(\mu_{\text {small }}-\mu_{\text {large }}\right) / \mu_{\text {large }}\right] \times N_{0} \times\left(\mathrm{e}^{\left.\mu_{\text {large }}-1\right)}\right)
\end{gathered}
$$

where $\mu_{\text {small }}$ is the growth rate $\left(\mathrm{d}^{-1}\right)$ of HNF and each ciliate taxon in the $<5$ and $<30 \mu \mathrm{m}$ fractions, respectively, $\mu_{\text {large }}$ is the growth rate of the $<30 \mu \mathrm{m}$ and total fractions respectively, and $N_{0}$ is the cell density of HNF and ciliates at the start of incubation in the $<30 \mu \mathrm{m}$ fraction and total fraction, respectively. These equations have previously been used for calculation of production and consumption of bacteria in sizefractionated water by Nagata (1988). The basic assumptions of the equations are that growth rates of protists in pond water and in the fractionated waters are equal, and that predation occurs only in the larger size fraction.

Production and predation thus estimated were converted into carbon flux (ng C ml-1 $\mathrm{d}^{-1}$ ) using cell volumes of HNF (Nakano \& Kawabata 2000) and ciliate taxa (Šimek et al. 1995) and the conversion factor (0.15 $\mathrm{g} \mathrm{C} \mathrm{ml}^{-1}$ ) (Laws et al. 1984).

\section{RESULTS}

Water temperature (Fig. 1A) in Furuike Pond decreased from September $1998\left(25.2^{\circ} \mathrm{C}\right)$ to January $1999\left(6.7^{\circ} \mathrm{C}\right)$ and increased to August $1999\left(28.8^{\circ} \mathrm{C}\right)$. The concentration of chlorophyll a ranged between 6.7 and $191 \mu \mathrm{g} \mathrm{l^{-1 }}$ with 2 peaks, in October and April (Fig. 1A). The phytoplankton was dominated by Microcystis aeruginosa (Cyanophyceae) throughout the summer months, from September to November 1998, and again from May to August 1999. In the winter, from December to April, Nitzschia spp. (Bacillariophyceae) and Synedra sp. (Bacillariophyceae) were dominant.

High cell densities of bacteria were detected in September $1998\left(3.8 \times 10^{7}\right.$ cells ml $\left.{ }^{-1}\right)$ and April 1999 $\left(3.5 \times 10^{7}\right.$ cells ml $\left.^{-1}\right)$, and bacterial cell density in other months did not show seasonal trends, ranging between $1.2 \times 10^{7}$ cells ml ${ }^{-1}$ and $2.1 \times 10^{7}$ cells $\mathrm{ml}^{-1}$ (Fig. 1B).

Cell densities of HNF (Fig. 1B) increased from December $1998\left(0.43 \times 10^{4}\right.$ cells ml $\left.^{-1}\right)$ to March 1999, when they reached their maximum $\left(2.25 \times 10^{4}\right.$ cells $\mathrm{ml}^{-1}$ ) and then decreased again with some fluctuations.

Densities of ciliates (Fig. 1C) fluctuated between 136 and 1000 cells $\mathrm{ml}^{-1}$ with 2 peaks, in December and April. The dominant ciliate species, based on their biomass, were Strobilidium sp., Cinetochilum margaritaceum, Urotricha spp., Tintinopsis sp., Halteria grandinella and Cyclidium glaucoma. The general pattern of their succession is shown in Fig. 2.

The patterns of seasonal change for rotifers and copepods were similar (Fig. 1C,D) from September to December. On the basis of densities of individuals, the dominant rotifer species at that time were Keratella 


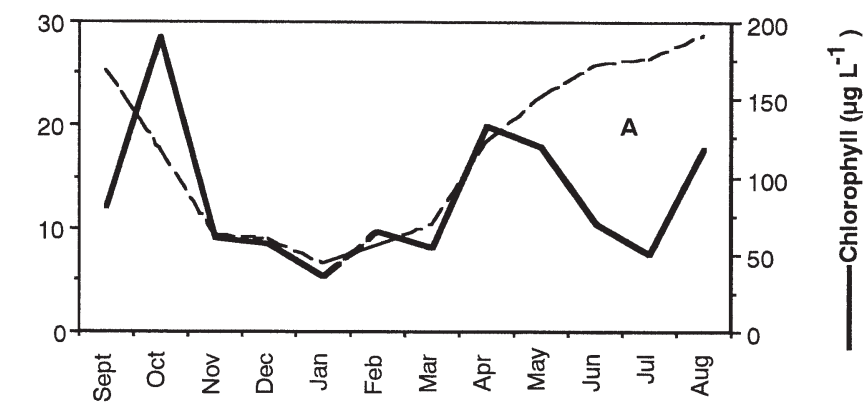



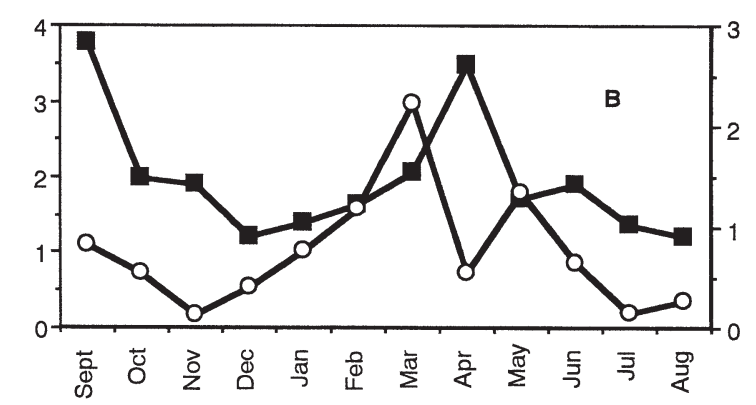



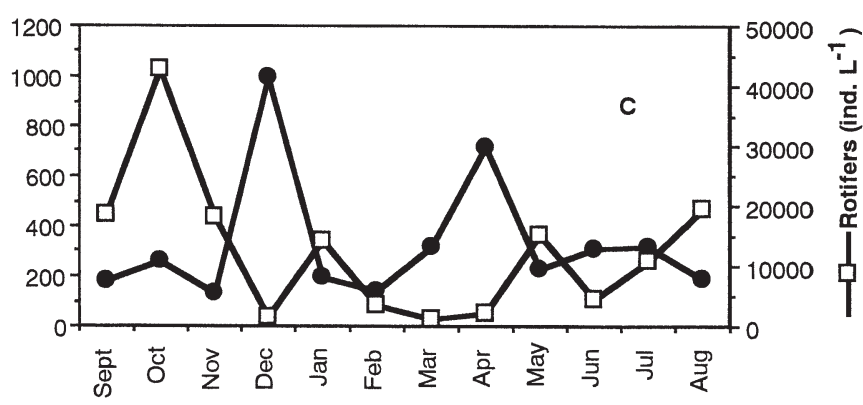



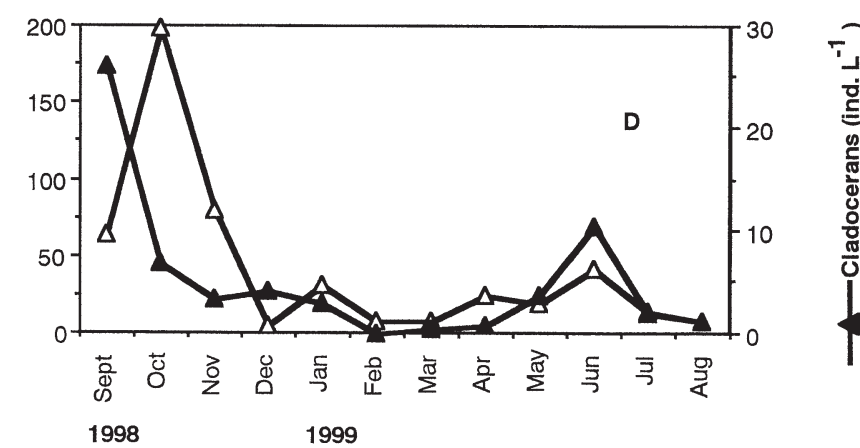

Fig. 1. Seasonal changes in (A) water temperature and chlorophyll a concentration; (B) density of bacteria and heterotrophic nanoflagellates (HNF); (C) density of ciliates and rotifers; and (D) densities of copepods and cladocerans in Furuike Pond during the study period

cochlearis and Polyarthra vulgaris, and they continued to be dominant in January and February. $K$. cochlearis and Trichocerca similis dominated from March to May, and Cephalodella sp. and P. vulgaris from June to August, when numbers began to rise again.
The predominant copepod was Cyclops vicinus; calanoids were also found but only during December. The pattern of seasonal abundance of Cladocera was similar to that of rotifers and copepods but their maximum occurred earlier, in September (26.0 ind. $\mathrm{l}^{-1}$ ). During the present study Diaphanosoma brachyurum was most abundant between September and November before being joined by Bosmina longirostris between December and February, Chydorus sp. in March and D. brachyuram again from April onwards.

In bottle incubation experiments, some ciliate cells did unfortunately pass through the $5 \mu \mathrm{m}$ mesh, though they were a small proportion of the total (Table 1). Similar results have been noted by Jürgens et al. (1999). In the water screened through the $30 \mu \mathrm{m}$ mesh plankton net we sometimes detected the small rotifer Cephalodella (Table 1), which was usually attached to a colony of Microcystis aeruginosa (Cyanophyceae) and was observed picking at the cyanobacterial cells. Because of the observed feeding mode of this rotifer, we ignored it when considering predation pressure on HNF and ciliates.

The growth rates $\left(\mathrm{d}^{-1}\right)$ of HNF ranged between -0.22 and 1.07 in the $<5 \mu \mathrm{m}$ fraction, -0.32 and 0.39 in the $<30 \mu \mathrm{m}$ fraction, and -0.50 and 0.81 in total fraction (Table 2). There were no seasonal trends to the changes in HNF growth rates in the $<5 \mu \mathrm{m}$ fraction. We detected decreases in HNF growth rates in the $<30 \mu \mathrm{m}$ fraction relative to those in the $<5 \mu \mathrm{m}$ fraction in 9 out of 12 cases, and the decrease was assumed to be due to predation. There were increases in the HNF growth rates in the total fractions relative to those in the $<30 \mu \mathrm{m}$ fraction in 8 out of 12 cases, implying that the ciliates that might otherwise have preyed on the HNF were themselves being reduced in numbers.

Production rates of HNF ranged between -12.4 and $86.4 \mathrm{ng} \mathrm{C} \mathrm{ml}^{-1} \mathrm{~d}^{-1}$, and predation on HNF by ciliates between -25.6 and $52.2 \mathrm{ng} \mathrm{C} \mathrm{ml}^{-1} \mathrm{~d}^{-1}$ (Fig. 3A). The seasonal patterns of production and predation rates were similar (Fig. 3A): they decreased from September to December, tended to increase from January to March, decreased again in April and May, and became nearly constant from June onwards. In September, November, June, July and August, predation to production ratios ranged between 0.67 and 1.06 (Fig. 3B). Thus, production of HNF was nearly balanced by predation in those months. Predation on HNF by all predators combined showed no seasonal changes and we could not detect any significant relation between production of HNF and predation by total predators (Fig. 4A). Predation to production ratios by 




Table 1. Percentages of heterotrophic nanoflagellates (HNF) and ciliates found in the $<5$ or $<30 \mu \mathrm{m}$ fraction. The presence of rotifers found in the $<30 \mu \mathrm{m}$ fraction is also shown. ND: not detected

\begin{tabular}{|c|c|c|c|c|}
\hline & $\begin{array}{c}\text { HNF in } \\
<5 \mu \mathrm{m} \text { fraction }\end{array}$ & $\begin{array}{c}\text { Ciliates in } \\
<5 \mu \mathrm{m} \text { fraction }\end{array}$ & $\begin{array}{c}\text { Ciliates in } \\
<30 \mu \mathrm{m} \text { fraction }\end{array}$ & $\begin{array}{c}\text { Rotifers in } \\
<30 \mu \mathrm{m} \text { fraction }\end{array}$ \\
\hline Sep & 78 & 38 & 91 & + \\
\hline Oct & 86 & 23 & 97 & + \\
\hline Nov & 97 & 22 & 100 & ND \\
\hline Dec & 93 & 29 & 74 & ND \\
\hline Jan & 67 & 14 & 89 & + \\
\hline Feb & 87 & 14 & 99 & ND \\
\hline Mar & 76 & 21 & 67 & ND \\
\hline Apr & 93 & 28 & 80 & ND \\
\hline May & 75 & 52 & 74 & ND \\
\hline Jun & 70 & 22 & 100 & + \\
\hline Jul & 98 & 36 & 72 & + \\
\hline Aug & 90 & 35 & 92 & + \\
\hline Mean & 84 & 28 & 86 & - \\
\hline
\end{tabular}

all predators combined (Fig. 4B) fluctuated more $(-2.5$ to 9.3 ) than those by ciliates (-0.1 to 5.1, Fig. 3B).

The growth rates $\left(\mathrm{d}^{-1}\right)$ of the dominant ciliate taxa in the $<30 \mu \mathrm{m}$ and total fractions are shown in Table 3. We found decreases in the growth rates of each ciliate taxon in the total fraction, relative to those in the $<30 \mu \mathrm{m}$ fraction, in 4 out of 10 cases for Cinetochilum margaritaceum, 5 out of 11 cases for Urotricha spp., 6 out of 10 cases for Halteria grandinella and 7 out of 9 cases for Cyclidium glaucoma. This suggests that ciliates were consumed by predators larger than $30 \mu \mathrm{m}$ and that Cyclidium was the most vulnerable to predation among the dominant ciliate taxa.

Production rates of Cinetochilum margaritaceum ranged between -6.4 and $115.4 \mathrm{ng} \mathrm{C} \mathrm{ml}^{-1} \mathrm{~d}^{-1}$ while rates of predation were between -25.2 and $88.5 \mathrm{ng} \mathrm{C}$ $\mathrm{ml}^{-1} \mathrm{~d}^{-1}$ (Fig. 5A). There were no clear seasonal patterns in the production and predation rates of this

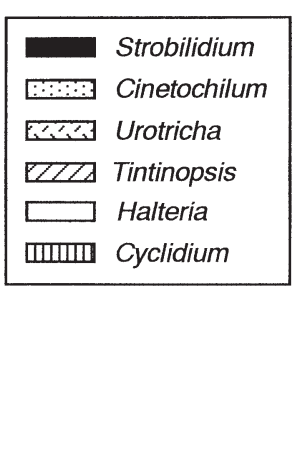

Fig. 2. Seasonal succession of dominant ciliate taxa (expressed as their percentages of the total ciliate biomass) during the study period in Furuike Pond

ciliate. In contrast, we did find seasonal trends in the production and predation rates of the other 3 dominant taxa.

Production and predation rates of Urotricha spp. varied between -6.9 and $17.1 \mathrm{ng} \mathrm{C} \mathrm{ml}^{-1} \mathrm{~d}^{-1}$ and between -6.9 and $17.9 \mathrm{ng} \mathrm{C} \mathrm{ml}^{-1} \mathrm{~d}^{-1}$, respectively. The seasonal pattern was bimodal with 2 peaks between December and February and between April and July (Fig. 5B). In some cases, predation rates exceeded production rates.

For Halteria grandinella, production and predation rates ranged between -13.4 and $46.2 \mathrm{ng} \mathrm{C} \mathrm{ml}^{-1} \mathrm{~d}^{-1}$ and between -18.6 and $21.0 \mathrm{ng} \mathrm{C} \mathrm{ml}^{-1} \mathrm{~d}^{-1}$, respectively. Relatively high rates of production and predation were detected from December to July (Fig. 5C).

The seasonal pattern of Cyclidium glaucoma was also bimodal with 2 peaks

Table 2. Population growth rates $\left(\mathrm{d}^{-1}\right.$, mean $\left.\pm \mathrm{SD}\right)$ of heterotrophic nanoflagellates in the $<5,<30 \mu \mathrm{m}$ and total fractions

\begin{tabular}{|lrrr|}
\hline & $<5 \mu \mathrm{m}$ & \multicolumn{1}{c}{$<30 \mu \mathrm{m}$} & \multicolumn{1}{c|}{ Total } \\
\hline Sep & $1.07 \pm 0.53$ & $0.13 \pm 0.10$ & $0.48 \pm 0.97$ \\
Oct & $0.27 \pm 0.18$ & $0.29 \pm 0.12$ & $0.55 \pm 0.06$ \\
Nov & $0.67 \pm 0.02$ & $-0.04 \pm 0.09$ & $0.28 \pm 0.06$ \\
Dec & $0.05 \pm 0.03$ & $-0.20 \pm 0.18$ & $-0.04 \pm 0.16$ \\
Jan & $0.33 \pm 0.38$ & $-0.32 \pm 0.08$ & $0.58 \pm 0.05$ \\
Feb & $0.05 \pm 0.01$ & $-0.07 \pm 0.03$ & $-0.43 \pm 0.03$ \\
Mar & $0.56 \pm 0.14$ & $0.39 \pm 0.03$ & $0.38 \pm 0.08$ \\
Apr & $-0.22 \pm 0.01$ & $0.23 \pm 0.20$ & $0.29 \pm 0.18$ \\
May & $0.18 \pm 0.18$ & $0.21 \pm 0.05$ & $0.65 \pm 0.20$ \\
Jun & $0.73 \pm 0.10$ & $0.18 \pm 0.09$ & $-0.50 \pm 0.05$ \\
Jul & $1.00 \pm 0.29$ & $0.34 \pm 0.10$ & $0.81 \pm 0.28$ \\
Aug & $0.58 \pm 0.09$ & $0.14 \pm 0.08$ & $-0.17 \pm 0.07$ \\
\hline
\end{tabular}



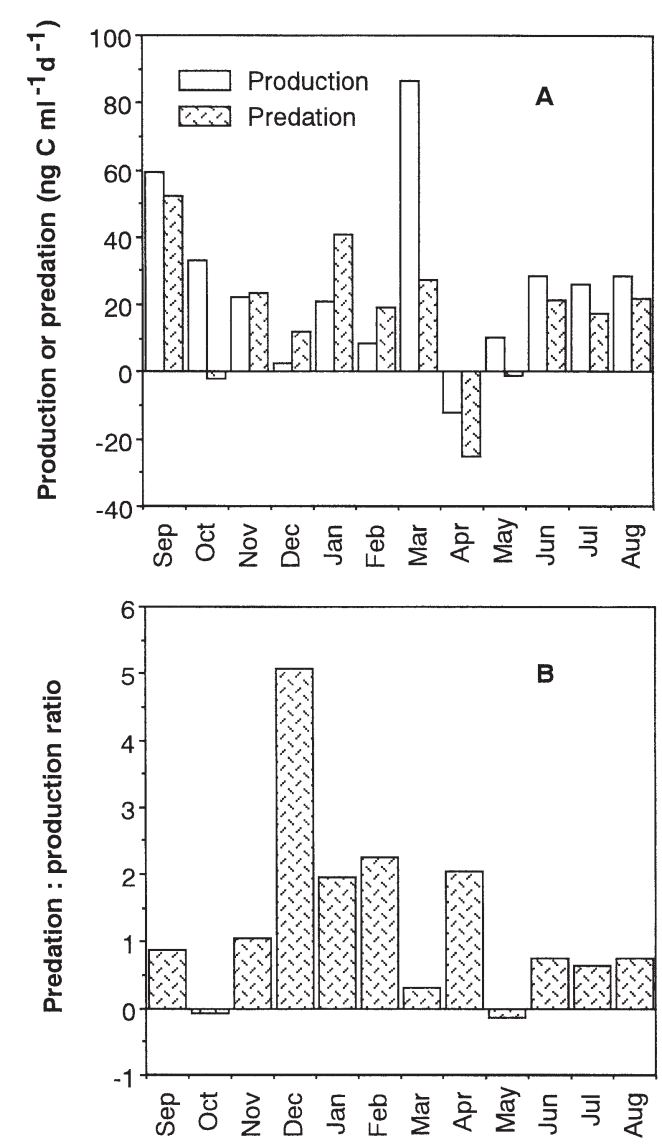

Fig. 3. Seasonal changes in HNF production and predation on HNF by (A) ciliates and (B) predation to production ratio in Furuike Pond during the study period

between September and December and between April and August (Fig. 5D). Its production and predation rates varied between 2.1 and $17.2 \mathrm{ng} \mathrm{C} \mathrm{ml} \mathrm{Cl}^{-1} \mathrm{~d}^{-1}$ and between -4.6 and $8.0 \mathrm{ng} \mathrm{C} \mathrm{ml} \mathrm{l}^{-1} \mathrm{~d}^{-1}$, respectively, and predation rates never exceeded production rates.


Fig. 4. Seasonal changes in HNF production and predation on HNF by (A) all predators combined and (B) predation to production ratio in Furuike Pond during the study period

Although we found seasonal trends in the production and predation rates of 3 out of 4 dominant taxa, predation to production ratios of dominant ciliates indicated that their production was not balanced by predation (Fig. 6).

Table 3. Population growth rates $\left(\mathrm{d}^{-1}\right.$, mean $\pm \mathrm{SD}$ ) of dominant ciliates (see 'Materials and methods') in the $<30 \mu \mathrm{m}$ and total fractions. ND: not determined

\begin{tabular}{|c|c|c|c|c|c|c|c|c|}
\hline & \multicolumn{2}{|c|}{ Cinetochilum margaritaceum } & \multicolumn{2}{|c|}{ Urotricha spp. } & \multicolumn{2}{|c|}{ Halteria grandinella } & \multicolumn{2}{|c|}{ Cyclidium glaucoma } \\
\hline & $<30 \mu \mathrm{m}$ & Total & $<30 \mu \mathrm{m}$ & Total & $<30 \mu \mathrm{m}$ & Total & $<30 \mu \mathrm{m}$ & Total \\
\hline Sep & $0.62 \pm 0.22$ & $0.90 \pm 0.29$ & $-0.09 \pm 0.26$ & $0.77 \pm 0.65$ & $0.13 \pm 0.04$ & $0.40 \pm 0.00$ & $0.49 \pm 0.35$ & $0.41 \pm 0.27$ \\
\hline Oct & $0.26 \pm 0.13$ & $0.21 \pm 0.16$ & ND & ND & ND & ND & $1.43 \pm 0.18$ & $1.38 \pm 0.00$ \\
\hline Nov & $-0.17 \pm 0.20$ & $0.51 \pm 0.26$ & $-0.99 \pm 0.42$ & $0.86 \pm 0.08$ & $0.28 \pm 0.11$ & $0.35 \pm 0.47$ & $1.10 \pm 0.00$ & $0.85 \pm 0.11$ \\
\hline Dec & $0.50 \pm 0.01$ & $0.12 \pm 0.03$ & $0.49 \pm 0.24$ & $0.27 \pm 0.16$ & $0.69 \pm 0.27$ & $0.38 \pm 0.06$ & $0.32 \pm 0.25$ & $0.09 \pm 0.12$ \\
\hline Jan & $-0.28 \pm 0.55$ & $1.49 \pm 0.28$ & $0.23 \pm 0.03$ & $0.41 \pm 0.16$ & $-0.10 \pm 0.30$ & $-0.51 \pm 0.22$ & ND & ND \\
\hline Feb & ND & ND & $0.70 \pm 0.31$ & $0.96 \pm 0.14$ & $0.90 \pm 0.32$ & $0.41 \pm 0.12$ & ND & ND \\
\hline Mar & $0.10 \pm 0.06$ & $0.26 \pm 0.03$ & $0.59 \pm 0.37$ & $0.72 \pm 0.47$ & $-0.56 \pm 0.09$ & $-0.95 \pm 0.15$ & ND & ND \\
\hline Apr & $1.09 \pm 0.19$ & $0.83 \pm 0.26$ & $-0.16 \pm 0.02$ & $-0.59 \pm 0.04$ & ND & ND & $1.37 \pm 0.40$ & $0.85 \pm 0.12$ \\
\hline May & $0.59 \pm 0.55$ & $0.59 \pm 0.55$ & $0.87 \pm 0.23$ & $0.52 \pm 0.16$ & $0.66 \pm 0.13$ & $0.93 \pm 0.11$ & $1.18 \pm 0.21$ & $1.41 \pm 0.07$ \\
\hline Jun & $0.37 \pm 0.20$ & $0.73 \pm 0.08$ & $0.79 \pm 0.33$ & $-0.15 \pm 0.24$ & $0.06 \pm 0.81$ & $0.23 \pm 0.40$ & $0.42 \pm 0.11$ & $0.63 \pm 0.14$ \\
\hline Jul & ND & ND & $1.86 \pm 0.18$ & $-0.37 \pm 0.85$ & $0.56 \pm 0.35$ & $-0.28 \pm 0.16$ & $0.65 \pm 0.10$ & $0.35 \pm 0.07$ \\
\hline Aug & $0.86 \pm 0.22$ & $0.84 \pm 0.44$ & $-0.26 \pm 0.06$ & $1.02 \pm 0.22$ & $-0.09 \pm 0.14$ & $-0.66 \pm 0.05$ & $0.95 \pm 0.57$ & $0.65 \pm 0.29$ \\
\hline
\end{tabular}





Fig. 5. Seasonal changes in production and predation of (A) Cinetochilum margaritaceum, (B) Urotricha spp., (C) Halteria grandinella and (D) Cyclidium glaucoma in Furuike Pond during the study period

Table 4. Results of logarithmic regression analyses between HNF production $\left(P_{\mathrm{HNF}}\right)$ and predation on HNF by ciliates $\left(M_{\mathrm{Cil}}\right)$, between production of Cinetochilum margaritaceum $\left(P_{\text {Cin }}\right)$ and predation on $C$. margaritaceum by predators $\left(M_{\text {Cin }}\right)$, and between production of Cyclidium glaucoma $\left(P_{\mathrm{Cyc}}\right)$ and predation on C. glaucoma by predators $\left(M_{\mathrm{Cyc}}\right)$

\begin{tabular}{|lcccc|}
\hline \multicolumn{2}{c}{ Variable } & $\mathrm{n}$ & $\mathrm{r}^{2}$ & $\mathrm{p}$ \\
Independent & Dependent & & & \\
\hline$P_{\mathrm{HNF}}$ & $M_{\mathrm{Cil}}$ & 9 & 0.471 & $<0.05$ \\
$P_{\mathrm{Cin}}$ & $M_{\mathrm{Cin}}$ & 4 & 0.938 & $<0.05$ \\
$P_{\mathrm{Cyc}}$ & $M_{\mathrm{Cyc}}$ & 7 & 0.742 & $<0.02$ \\
\hline
\end{tabular}
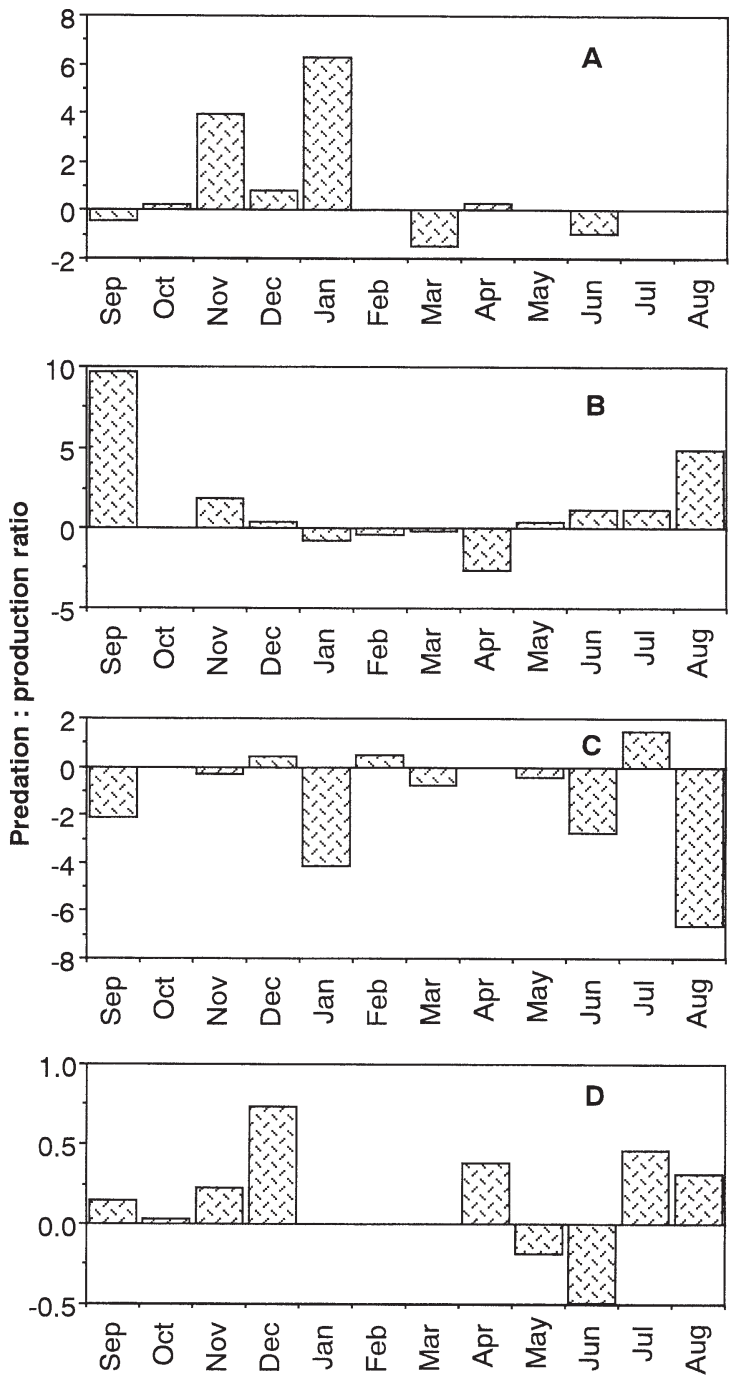

Fig. 6. Seasonal changes in predation to production ratio of (A) Cinetochilum margaritaceum, (B) Urotricha spp., (C) Halteria grandinella and (D) Cyclidium glaucoma in Furuike Pond during the study period

Logarithmic regression analysis showed a significant correlation $(\mathrm{p}<0.05)$ between HNF production and predation on HNF by ciliates (Table 4 ). There was a significant logarithmic $(\mathrm{p}<0.05)$ correlation for Cinetochilum margaritaceum (Table 4) and a significant $(\mathrm{p}<0.02)$ logarithmic correlation for Cyclidium glaucoma (Table 4). No significant correlations were found for Urotricha spp. and Halteria grandinella.

\section{DISCUSSION}

Growth rates of HNF in the $<5 \mu \mathrm{m}$ fraction of the present study fall within the range of those in the literature (Table 5) and are almost equal to those found by Nagata (1988) and Weisse (1997). Growth rates of each 
Table 5. Population growth rates of HNF and ciliates determined by the size-fractionation method in the literature

\begin{tabular}{|c|c|c|c|c|c|}
\hline Lake & Taxon & Temp. $\left({ }^{\circ} \mathrm{C}\right)$ & Fraction $(\mu \mathrm{m})$ & Growth rate $\left(\mathrm{d}^{-1}\right.$ & Source \\
\hline \multicolumn{6}{|l|}{ HNF } \\
\hline Arlington & Assemblages & $10-33$ & $<5$ & $0.07-2.57$ & Chrzanowski \& Šimek (1993) \\
\hline Biwa & Assemblages & $18-27$ & $<25$ & $-0.34-1.11$ & Nagata (1988) \\
\hline Constance & Assemblages & $5-23$ & $<10$ & $-0.13-1.76$ & Weisse (1997) \\
\hline Furuike & Assemblages & $7-29$ & $<5$ & $-0.22-1.07$ & Present study \\
\hline Michigan & $\begin{array}{l}\text { Chromulina sp. } \\
\text { Katablepharis ovalis }\end{array}$ & $2-20$ & $<3$ and 8 & $\begin{array}{l}0-0.60 \\
0-1.05\end{array}$ & Carrick et al. (1992) \\
\hline Tyrrel & Assemblages & - & $<20$ & $0.52-0.65$ & Pace \& Vaque (1994) \\
\hline Upton & Assemblages & - & $<20$ & $0.40-0.50$ & \\
\hline West Long & Assemblages & - & $<20$ & $0.44-0.90$ & \\
\hline \multicolumn{6}{|l|}{ Ciliates } \\
\hline Furuike & $\begin{array}{l}\text { Cinetochilum margaritaceum } \\
\text { Urotricha spp. } \\
\text { Halteria grandinella } \\
\text { Cyclidium glaucoma }\end{array}$ & $7-29$ & $<30$ & $\begin{array}{c}-0.28-1.09 \\
-0.99-1.86 \\
-0.56-0.90 \\
0.32-1.43\end{array}$ & Present study \\
\hline Michigan & $\begin{array}{l}\text { Tintinidium sp. } \\
\text { Codonella sp. } \\
\text { Halteria sp. } \\
\text { Strobilidium sp. } \\
\text { Urotricha sp. } \\
\text { Vorticella sp. }\end{array}$ & $2-20$ & $<3$ and 8 & $\begin{array}{l}0-0.84 \\
0-0.56 \\
0-1.45 \\
0-2.28 \\
0-1.25 \\
0-0.98\end{array}$ & Carrick et al. (1992) \\
\hline Ontario & Assemblages & $3.4-13$ & $<44$ & $-0.30-0.85$ & Taylor \& Johannsson (1991) \\
\hline Sobygard & $\begin{array}{l}\text { Urotricha spp. } \\
\text { Rimostrombidium brachykinetum } \\
\text { Halteria grandinella } \\
\text { Monodinium sp. } \\
\text { Lagynophrya sp. }\end{array}$ & $20-25$ & $<10$ & $\begin{array}{c}1.00-2.24 \\
1.51-1.52 \\
1.64-1.90 \\
0-2.10 \\
1.64-2.35\end{array}$ & Jürgens et al. (1999) \\
\hline Tyrrel & Assemblages & - & $<20$ & $0.19-0.24$ & Pace \& Vaque (1994) \\
\hline Upton & Assemblages & - & $<20$ & $0-0.46$ & \\
\hline West Long & Assemblages & - & $<20$ & $0.22-0.52$ & \\
\hline
\end{tabular}

ciliate taxon in the present study also overlap the range of those found in previous studies (Table 5), except for those determined in a hypereutrophic Danish lake (Jürgens et al. 1999), which are higher than those in the present study. Although the information presented in Table 5 covers lakes in various trophic states from oligotrophic to hypereutrophic, growth rates of their protists are rather similar. The reason for this is still unclear, and we have to collect more information about seasonal changes in protist growth rates in lakes of different trophic state.

It is well known that HNF release nitrogen (Goldman et al. 1985, Nakano 1994a,b) and phosphorus (Andersen et al. 1986, Nakano 1994a,c). Metazoan zooplankton also release nutrients (Lehman 1980, Lehman \& Scavia 1982). The released nutrients may enhance growth of flagellates if they are mixotrophic. However, in the present study, we examined protists that did not have chlorophyll autofluorescence. Hence, we do not have to consider enhancement of mixotrophic flagellate growth by released nutrients in the present study. The released nutrients may also enhance growth of bacteria and picophytoplankton, both of which serve as prey for HNF and ciliates, and this may also affect growth of the protists (indirect effect; Lehman 1980, Lehman \& Scavia 1982). The dissolved phosphorus concentration in Furuike Pond is high, ranging between 10 and $250 \mu \mathrm{g} \mathrm{l}^{-1}$ (Miyagaki \& Nakano unpubl. data). Thus, phosphorus limitation on bacterial growth in Furuike Pond is unlikely. In contrast, concentrations of dissolved inorganic nitrogen are in most cases low $\left(<40 \mu \mathrm{g} \mathrm{l}^{-1}\right)$ in the pond ( $\mathrm{M}$. Hirose \& S. Nakano unpubl. data), and this may affect bacterial growth through nitrogen limitation. In a preliminary experiment, we examined bacterial growth on dissolved organic matter in Furuike Pond in the system with and without nitrogen $\left(\mathrm{NH}_{4} \mathrm{Cl}\right)$ addition. In the experiment, we detected increased bacterial abundance in both systems and a higher abundance in the nitrogen addition system (K. Nishii \& S. Nakano unpubl. data). Thus, bacterial growth in Furuike Pond may be limited by nitrogen. However, the increase in bacterial abundance was detected on the second day of incubation in both systems. In the present study, the duration of our incubation was $1 d$, suggesting that bacterial growth was negligible even if nitrogen was supplied. Thus, we likely can ignore enhancement of the protistan growth rate by increased bacter- 
ial abundance through an indirect effect in the present study.

There were coupled oscillations between cell densities of HNF and ciliates during the study (Fig. 1). In most cases, growth rates of HNF in the $<30 \mu \mathrm{m}$ fraction were lower than those in the $<5 \mu \mathrm{m}$ fraction (Table 2), suggesting that the population in the $<30 \mu \mathrm{m}$ fraction was being suppressed. The seasonal pattern of predation rates on HNF by ciliates was similar to that of HNF production rates (Fig. 3A), predation on HNF by ciliates in most cases accounted for a large portion of HNF production (Fig. 3B), and there were significant relations between production rates of HNF and predation rates on HNF by ciliates (Table 4). These results indicate that ciliates are major consumers of HNF in Furuike Pond, and that loss to predation by ciliates is one of the most important loss processes of HNF in the pond. Thus, our results are similar to those of Weisse et al. (1990) and Weisse (1991), despite the fact that those studies were conducted in a mesotrophic to eutrophic alpine lake.

We have not yet determined which ciliate taxa were responsible for the predation on HNF. According to Foissner \& Berger (1996), Cyclidium consumes bacteria, Cinetochilum and Halteria feed on bacteria and algae, while Urotricha ingests bacteria, algae and HNF. Jürgens et al. (1996) noted that Halteria was an efficient predator of HNF. All except a few of the estimates of production for the dominant ciliate taxa were less than the estimated predation loss of HNF on the same date, suggesting that they do consume HNF. Indeed, the seasonal succession of Halteria (Fig. 2) was similar to the seasonal changes in predation to production ratio of HNF (Fig. 3). However, in some cases, production rates of dominant ciliates such as Cinetochilum margaritaceum and Halteria grandinella (Fig. 5) were much higher than the predation rates of HNF (Fig. 3), so there must be other food sources for these ciliates, but this does not exclude them also consuming HNF. It is therefore impossible to identify precisely which ciliate taxa were the most important predators of HNF in the present study.

In contrast, we did not detect coupled oscillations in the seasonal abundances of HNF and metazoan zooplankton (Fig. 1), nor were there significant relations between HNF production rates and predation rates on HNF by total predators (Fig. 4). These results suggest that predation by metazoan zooplankton is of minor importance as a loss process for HNF. Using 3 ciliates, 2 rotifers, 6 cladocerans, 3 copepods and 2 HNF species in laboratory experiments, Jürgens et al. (1996) reported that the most efficient predators of HNF were oligotrichous ciliates, that there were only slight differences in weight-specific clearance rates on HNF among rotifers, calanoid copepods and cladocerans, and that the most inefficient predators of HNF were cyclopoid copepods. Since the densities of cladocerans are usually low in Furuike Pond (Fig. 1D, Nakano et al. 1998a), their predation pressure on HNF is likely to be low and, although the abundance of cyclopoid copepods is usually higher than that of cladocerans (Nakano et al. 1998a), they too are unlikely to be important consumers of HNF. Cyclopoid copepods are herbivores or omnivores, but are not filter feeders, and tend to take larger prey. Since the average cell size of HNF in Furuike Pond is $5.1 \mu \mathrm{m}$ diameter (Nakano \& Kawabata 2000), they may be too small to be eaten by copepods.

In 8 out of 12 cases, HNF growth rates were higher in the total fractions than in the $<30 \mu \mathrm{m}$ fraction (Table 2). In 10 out of 12 cases we found that predation rates by total predators were lower than those by ciliates alone (Figs 3 \& 4). This suggests that growth of HNF is enhanced by the presence of metazoan zooplankton, and there may be a trophic cascade among the HNF, ciliates and metazoan zooplankton: for example, metazoan zooplankton consuming ciliates, which in turn consume HNF. However, this kind of trophic cascade has not yet been fully shown. Daphnia is often used to examine trophic cascades in lake food webs, but this cladoceran is a predator of HNF (Pace \& Funke 1991, Nakano et al. 1998b, Pace et al. 1998). Using the cyclopoid Cyclops abyssorum, which preyed on other metazooplankton and ciliates, Wickham (1995) found the trophic cascade among the cyclopoid, other metazooplankton and 2 ciliate taxa (Strobilidium and Urotricha). There is a need for further studies on the trophic cascade in aquatic ecosystems with special reference to microbial food webs.

One may think that low growth rates of HNF in the $<30 \mu \mathrm{m}$ fraction relative to those in the $<5 \mu \mathrm{m}$ fraction (Table 2) were due to food resource limitation induced by the bacterivorous ciliates in the former fraction, and that enhanced growth of HNF in the presence of metazoan zooplankton (Table 2) was due to a removal of a competitor (bacterivorous ciliates) for food resources. In our previous study (Nakano et al. 1998a), daily consumption of bacteria by HNF and ciliates combined in Furuike Pond accounted for less than $30 \%$ of the bacterial standing crop in most case. High consumption was detected when HNF cell densities were high $\left(>7.8 \times 10^{4}\right.$ cells ml $^{-1}$; Nakano et al. 1998a), but this was not the case in the present study since the HNF cell densities $\left(<2.2 \times 10^{4}\right.$ cells ml ${ }^{-1}$; Fig. 1B) was lower than those observed by Nakano et al. (1998a). Thus, it is likely that the bacterial resource is not exhausted by protistan grazing within $1 \mathrm{~d}$. Hence, we think that the changes in growth rates among size fractions in Table 2 are the result of predation on HNF by ciliates and trophic cascade among HNF, ciliates and meta- 
zoan zooplankton, though the relation between bacterial density and grazing rates on bacteria by HNF and ciliates in Fig. 5 of Nakano et al. (1998a) suggested food limitation on the protists in Furuike Pond.


ates Cinetochilum margaritaceum and Halteria grandinella were not generally enhanced by the removal of predators (Table 3). Also, the relation between rates of production and predation of $H$. grandinella was not significant. Although we found a significant relation between rates of production and predation of C. margaritaceum (Table 4), the seasonal trend in predation on this ciliate differed from that of production (Fig. 5), and generally predation rates were much lower than production rates (Fig. 6). These observations suggest that predation is not a major loss process for these 2 ciliate taxa. Halteria has a strategy to escape from predation: Gilbert (1994) has reported that the jumping behavior of this ciliate is an effective mechanism for escape from rotifers, and Wiackowski et al. (1994) noted that Halteria is less vulnerable than other species to predation by cladocerans and copepods. C. margaritaceum is usually found in plankton or benthos and we often observed, under the microscope, this protist moving around larger particles such as Microcystis colonies and detrital particles. This behavior may be effective against predation, since many zooplankters show size-selective grazing and tend to reject large (for example, $>20 \mu \mathrm{m}$ ) particles (Burns 1968, DeMott 1985, Nagata \& Okamoto 1988).

Growth rates of Urotricha spp. did not generally increase with removal of predators (Table 3), and the relation between rates of production and predation was insignificant. However, from April to July, predation rates on Urotricha spp. generally exceeded its production (Figs $5 \& 6$ ). During that period, the ciliate was dominant (Fig. 2), and the abundances of cyclopoid copepods and cladocerans increased (Fig. 1). Since cyclopoid copepods are inefficient predators of ciliates relative to cladocerans (Wiackowski et al. 1994), the high predation rates on Urotricha spp. were perhaps attributable to predation by cladocerans. Indeed, growth rates of this ciliate did increase with removal of predators during this period (Table 3). Thus, since predation was apparently important for loss of this ciliate only during that limited season, we could not find a significant overall relation between its production and predation but it may be vulnerable to predation by cladocerans.

In most cases, growth rates of Cyclidium glaucoma were increased by removal of predators (Table 3). We also found a significant relation between production and predation of this ciliate (Table 4). Predation occurred when the ciliate dominated (Fig. 2), though predation rates were usually lower than production rates (Figs $5 \& 6$ ). Predation by metazoan zooplankton is, therefore, an important loss processes for this ciliate in Furuike Pond.

We did not examine predation on HNF and small ciliates by large ciliates but we think that predation by large ciliates on other ciliate species is negligible in Furuike Pond, since small ciliates were dominant throughout the present study (Fig. 2, Nakano et al. 1998a).

In most eutrophic and hypereutrophic lakes dominated by bloom-forming cyanobacteria, phytoplankton edible by zooplankton are scarce, and protists may be important alternative food sources. In the present study, we found that the food linkage between HNF and ciliates was substantial but not between HNF and metazoan zooplankton, and that the trophic linkages from Urotricha spp. and Cyclidium glaucoma to metazoan predators were active, whereas those from Cinetochilum margaritaceum and Halteria grandinella were not. Also, we showed over a 1 yr period that HNF production was almost balanced by loss to predation by ciliates, and that loss processes other than predation might be important for some ciliate taxa. As the next step, simultaneous measurements of matter flux from the microbial food web to metazoan zooplankton and from edible phytoplankton to the zooplankton will be required. In addition to this, more knowledge of the ecology of ubiquitous ciliates, such as Cinetochilum and Halteria, whose loss processes are still unclear, may be important if we are to understand matter flux through protists in hypereutrophic lakes.

Acknowledgements. We are grateful to Yaho Hirose, Kenji Nishii and the members of the Ecosystem Conservation Laboratory, Ehime University for their advice, discussions and encouragement throughout the study. Thanks are also due to Dr Hiroshi Ueda for his identification of zooplankton and Dr Mary Morris for her correction of English and constructive comments on the earlier version of the manuscript. This study was partly supported by a Japanese Ministry of Education, Science and Culture Grant-in-Aid for Creative Basic Research (09NP1501), 'An interactive study on biodiversity conservation under global change and bio-inventory management system', by a grant-in aid from the Ministry of Education, Science, Sports and Culture, Japan (No. 08308031) and by the Showa Shell Sekiyu Foundation for Promotion of Environmental Research.

\section{LITERATURE CITED}

Andersen OK, Goldman JC, Caron DA, Dennett MR (1986) Nutrient cycling in a microflagellate food chain: III. Phosphorus dynamics. Mar Ecol Prog Ser 31:47-55

Bloem J, Bar-Gilissen MJB (1989) Bacterial activity and protozoan grazing potential in a stratified lake. Limnol Oceanogr 34:297-309

Brett MT, Wiackowski K, Lubnow FS, Muller-Solger A, Elser JJ, Goldman CR (1994) Species-dependent effects of zoo- 
plankton on planktonic ecosystem processes in Castle Lake, California. Ecology 75:2243-2254

Burns CW (1968) The relationship between body size of filterfeeding Cladocera and the maximum size of particle ingested. Limnol Oceanogr 13:675-678

Burns CW, Schallenberg M (1996) Relative impacts of copepods, cladocerans and nutrients on the microbial food web of a mesotrophic lake. J Plankton Res 18:683-714

Caron DA (1983) Technique for enumeration of heterotrophic and phototrophic nanoplankton, using epifluorescence microscopy, and comparison with other procedures. Appl Environ Microbiol 46:491-498

Carrick HJ, Fahnenstiel GLF, Stoermer EF, Wetzel RG (1991) The importance of zooplankton-protozoan trophic couplings in Lake Michigan. Limnol Oceanogr 36:1335-1345

Carrick HJ, Fahnenstiel GL, Taylor WD (1992) Growth and production of planktonic protozoa in Lake Michigan: in situ versus in vitro comparisons and importance to food web dynamics. Limnol Oceanogr 37:1221-1235

Chrzanowski TH, Simek K (1990) Prey-size selection by freshwater flagellated protozoa. Limnol Oceanogr 35: 1429-1436

DeMott WR (1985) Relations between filter mesh-size, feeding mode, and capture efficiency for cladocerans feeding on ultrafine particles. Arch Hydrobiol Beih Ergebn Limnol 21:125-134

Dobberfuhl DR, Miller R, Elser JJ (1997) Effects of a cyclopoid copepod (Diacyclops thomasi) on phytoplankton and the microbial food web. Aquat Microb Ecol 12:29-37

Dolan JR, Gallegos CL (1991) Trophic coupling of rotifers, microflagellates, and bacteria during fall months in the Rhode River Estuary. Mar Ecol Prog Ser 77:147-156

Foissner W, Berger H (1996) A user-friendly guide to the ciliates (Protozoa, Ciliophora) commonly used by hydrobiologists as bioindicators in rivers, lakes, and waste waters, with notes on their ecology. Freshw Biol 35:375-482

Gilbert JJ (1994) Jumping behavior in the oligotrich ciliates Strobilidium verox and Halteria grandinella, and its significance as a defense against rotifer predators. Microb Ecol 27:189-200

Goldman JC, Caron DA, Andersen OK, Dennett MR (1985) Nutrient cycling in a microflagellate food chain: I. Nitrogen dynamics. Mar Ecol Prog Ser 24:231-242

Hansen AM (2000) Response of ciliates and Cryptomonas to the spring cohort of a cyclopoid in a shallow hypereutrophic lake. J Plankton Res 22:185-203

Havens KE, Beaver JR (1997) Consumer vs. resource control of ciliate protozoa in a copepod-dominated subtropical lake. Arch Hydrobiol 140:491-511

Jürgens K (1994) Impact of Daphnia on planktonic microbial food webs: a review. Mar Microb Food Webs 8:295-324

Jürgens K, Wickham SA, Rothhaupt KO, Santer B (1996) Feeding rates of macro- and microzooplankton on heterotrophic nanoflagellates. Limnol Oceanogr 41:1833-1839

Jürgens K, Skibbe O, Jappesen E (1999) Impact of metazooplankton on the composition and population dynamics of planktonic ciliates in a shallow, hypertrophic lake. Aquat Microb Ecol 17:61-75

Lampert W, Sommer U (1997) Trophic classification of lakes. In: Limnoecology. Oxford University Press, New York

Laws EA, Haas LW, Bienfang PK, Eppley RW, Harrison RG, Karl DM, Marra J (1984) High phytoplankton growth and production rates in oligotrophic Hawaiian coastal waters. Limnol Oceanogr 29:1161-1169

Lehman JT (1980) Release and cycling of nutrients between planktonic algae and herbivores. Limnol Oceanogr 25: 620-632
Lehman JT, Scavia D (1982) Microscale patchiness of nutrients in plankton communities. Science 216:729-730

Marchessault P, Mazumder A (1997) Grazer and nutrient impacts on epilimnetic ciliate communities. Limnol Oceanogr 42:893-900

Moran R, Porath D (1980) Chlorophyll determination in intact tissues using N,N-dimethylformamide. Plant Physiol 65: $478-479$

Nagata T (1988) The microflagellate-picoplankton food linkage in the water column of Lake Biwa. Limnol Oceanogr 33:504-517

Nagata T, Okamoto K (1988) Filtering rates on natural bacteria by Daphnia longispina and Eodiaptomus japonicus in Lake Biwa. J Plankton Res 10:835-850

Nakano S (1994a) Carbon:nitrogen:phosphorus ratios and nutrient regeneration of a heterotrophic flagellate fed on bacteria with different elemental ratios. Arch Hydrobiol 129:257-271

Nakano S (1994b) Rates and ratios of nitrogen and phosphorus by a bacterivorous flagellate. Jpn J Limnol 55: $115-223$

Nakano S (1994c) Estimation of phosphorus release rate by bacterivorous flagellates in Lake Biwa. Jpn J Limnol 55: 201-211

Nakano S, Kawabata Z (2000) Changes in cell volume of bacteria and heterotrophic nanoflagellates in a hypereutrophic pond. Hydrobiologia 428:197-203

Nakano S, Ishii N, Manage PM, Kawabata Z (1998a) Trophic roles of heterotrophic nanoflagellates and ciliates among planktonic organisms in a hypereutrophic pond. Aquat Microb Ecol 16:153-161

Nakano S, Koitabashi T, Ueda T (1998b) Seasonal changes in abundance of heterotrophic nanoflagellates and their consumption of bacteria in Lake Biwa with special reference to trophic interactions with Daphnia. Arch Hydrobiol 142: 21-34

Pace ML, Funke E (1991) Regulation of planktonic microbial communities by nutrients and herbivores. Ecology 72 : 904-914

Pace ML, Vaque D (1994) The importance of Daphnia in determining mortality rates of protozoans and rotifers in lakes. Limnol Oceanogr 39:985-996

Pace ML, McManus GB, Findlay SEG (1990) Planktonic community structure determines the fate of bacterial production in a temperate lake. Limnol Oceanogr 35: 795-808

Pace ML, Cole JJ, Carpenter SR (1998) Trophic cascades and compensation: differential responses of microzooplankton in whole-lake experiments. Ecology 79:138-152

Patterson DJ, Hedley S (1992) Free-living freshwater protozoa. A colour guide. Wolfe Publishing Ltd, London

Porter KG, Feig YS (1980) The use of DAPI for identifying and counting aquatic microflora. Limnol Oceanogr 25:943-948

Sanders RW, Porter KG, Bennet SJ, DeBiase AE (1989) Seasonal patterns of bacterivory by flagellates, ciliates, rotifers, and cladocerans in a freshwater planktonic community. Limnol Oceanogr 34:673-687

Šimek K, Straskrabova V (1992) Bacterioplankton production and protozoan bacterivory in a mesotrophic reservoir. J Plankton Res 14:773-787

Šimek K, Macek M, Seda J, Vyhnalek V (1990) Possible food chain relationships between bacterioplankton, protozoans and cladocerans in a reservoir. Int Rev Hydrobiol 75: 583-596

Šimek K, Bobkova KJ, Macek M, Nedoma J (1995) Ciliate grazing on picoplankton in a eutrophic reservoir during the summer phytoplankton maximum: a study at the spe- 
cies and community level. Limnol Oceanogr 40:1077-1090

Taylor D, Johannsson OE (1991) A comparison of estimates of productivity and consumption by zooplankton for planktonic ciliates in Lake Ontario. J Plankton Res 13: 363-372

Taylor D, Sanders RW (1991) Protozoa. In: Thorp JH, Covich AP (eds) Ecology and classification of North American freshwater invertebrates. Academic Press, San Diego, p 37-93

Weisse T (1991) The annual cycle of heterotrophic freshwater nanoflagellates: role of bottom-up versus top-down control. J Plankton Res 13:167-185

Weisse T (1997) Growth and production of heterotrophic

Editorial responsibility: David Caron,

Los Angeles, California, USA nanoflagellates in a meso-eutrophic lake. J Plankton Res 19:703-722

Weisse T, Muller H, Pinto-Coelho RM, Schweizer A, Springmann D, Baldringer G (1990) Response of the microbial loop to the phytoplankton spring bloom in a large prealpine lake. Limnol Oceanogr 35:781-794

Wiackowski K, Brett MT, Goldman CR (1994) Differential effects of zooplankton species on ciliate community structure. Limnol Oceanogr 39:486-492

Wickham SA (1995) Trophic relations between cyclopoid copepods and ciliated protists: complex interactions link the microbial and classic food webs. Limnol Oceanogr 40: $1173-1181$

Submitted: March 16, 2001; Accepted: July 24, 2001

Proofs received from author(s): September 11, 2001 